\title{
My experience with One Health: between realism and optimism
}

\author{
Alejandro Gaviria \\ School of Economics, Universidad de los Andes, Bogotá 111711, Colombia. \\ Correspondence to: Mr. Alejandro Gaviria, School of Economics, Universidad de los Andes, Bogotá 111711, Colombia. \\ E-mail: agaviria@uniandes.edu.co
}

How to cite this article: Gaviria A. My experience with One Health: between realism and optimism. One Health Implement Res 2021;1:14-6. https://dx.doi.org/10.20517/ohir.2020.001

Received: 14 Dec 2020 First Decision: 19 Feb 2021 Revised: 30 Mar 2021 Accepted: 12 Apr 2021 Available online: 24 May 2021

Academic Editor: Jorg Heukelbach Copy Editor: Yue-Yue Zhang Production Editor: Yue-Yue Zhang

It is a privilege for me to share my views about my practical experience with both environmental health and the crucial idea of One Health. I am an economist who has devoted a good part of life to studying socioeconomic development. I spent several years of my life studying the social determinants of health, which gave me a better understanding of the need for interdisciplinary collaboration and the interdependence of human actions.

I was appointed Minister of Health of Colombia in 2012. I was minister for 6 years, from 2012 to 2018. I had the humbling opportunity to try to implement all that I had written about and recommended. Policymaking is often an exercise in frustration. You learned too soon that your powers are limited, that social change is complex and therefore that you had better find some pockets of possibility.

I am going to give a few examples of my experiences on the ground. These examples are illustrative. I will not rush to draw general conclusions from them. Overall, they underline the political complexities of implementing a One Health approach.

As minister of health of Colombia, I had to cope with the epidemics of Chikungunya and Zika (there were reports of ZVD clinical symptoms in more than 100,000 of people nationwide, the second highest number in clinical cases in Latin America) ${ }^{[1]}$. I felt powerless many times. In the face of the crisis, we tried to change

The Author(s) 2021. Open Access This article is licensed under a Creative Commons Attribution 4.0 International License (https://creativecommons.org/licenses/by/4.0/), which permits unrestricted use, sharing, adaptation, distribution and reproduction in any medium or format, for any purpose, even commercially, as long as you give appropriate credit to the original author(s) and the source, provide a link to the Creative Commons license, and indicate if changes were made. 
people's behavior, promote some preventive attitudes and make the case for a more comprehensive approach. It was difficult. I remember that I tried to explain in congress that theses epidemics were related to environmental problems well beyond our policy space. It sounded as if I were making excuses. The political debate was centered on fumigation campaigns and other short term (and ineffective) measures. The link between climate change and health outcomes seems remote and unproven.

My efforts of coordination and cooperation with other ministers were not very successful. We created an inter-sectorial commission for health. The environmental minister attended the first session, but then delegated to other people. In 6 years, I had only one bilateral meeting with the environmental minister. Public policy in practice takes place in silos. It is difficult to change this. Probably, it needs a commitment from the top, from the president. One Health needs a longer horizon, a type of structural thinking that is sometimes at odds with the impatience of everyday policymaking.

Effective coordination is not the only issue to resolve. There are also political challenges derived from the overreaching power of big companies that interfere with public health. I personally experienced these problems: an attempt to implement a soda tax was disrupted from the very beginning after an aggressive media campaign, orchestrated by economic conglomerates. The debate was not even allowed in congress. Industrial lobbyists were, in this case, very successful in using scientific doubts to their advantage.

There is also, I must acknowledge, some indifference on the part of the public about some of these issues. Mercury contamination is a huge problem in many communities in Colombia ${ }^{[2]}$. Some studies have shown deleterious effects on health and cognitive development ${ }^{[3]}$, but nobody seems to care. I say this as form of self-criticism. Environmental health can be set aside too easily with few political repercussions.

However, I don't want to be overly pessimistic. Oftentimes good policies can be implemented. Oftentimes we can make the difference. We were able in Colombia to stop the aerial fumigation of coca fields with the weed killer glyphosate. We made the connection between environmental degradation, lost livelihoods, and some adverse health effects: dermatological and respiratory problems, as well as a probable connection between a repeated exposure to glyphosate and lymphatic cancer.

I rely on my previous experience as a researcher. I had the opportunity to bring to the debate two articles written by former coauthors. The first uses a regression discontinuity approach to show a connection between aerial fumigation with glyphosate and spontaneous abortions in the south of Colombia ${ }^{[4]}$. The second uses a similar approach to show a connection between glyphosate use in agriculture and child mortality in Brazil ${ }^{[5]}$. Both articles had a huge impact. They captured the attention of the regulatory agencies and the press. In my opinion, they were fundamental.

The Constitutional Court in Colombia backed our arguments. The environmental authorities acted in accordance. Fumigations were suspended. There are now mounting pressures to resume them. However, our arguments (that somehow encompass the Berlin Principles) have prevailed so far.

I am an advocate of piece-meal social engineering. We need a comprehensive approach and a good normative foundation to trigger social change. Nevertheless, these are not sufficient. One Health is difficult. We also need brave leadership, and persistence. My experience shows that there are many forces that inhibit social change. We lose some battles, while we win others. Yet we have to maintain a bias for hope. 


\section{DECLARATIONS}

\section{Authors' contributions}

The author contribute solely to this article.

\section{Availability of data and materials}

Not applicable.

\section{Financial support and sponsorship}

None.

\section{Conflicts of interest}

The author declared that there are no conflicts of interest.

\section{Ethnic approval and consent to publication}

Not applicable.

\section{Consent for publication}

Not applicable.

\section{Copyright}

(c) The Author(s) 2021.

\section{REFERENCES}

1. Pacheco O, Beltrán M, Nelson CA, et al. Zika Virus Disease in Colombia - Preliminary Report. N Engl J Med 2020;383:e44. DOI PubMed

2. Paula Gutiérrez BF, Agudelo CAR. Fish as bioindicators: coal and mercury pollution in Colombia's ecosystems. Environ Sci Pollut Res Int 2020;27:27541-62. DOI PubMed

3. Bose-O'Reilly S, McCarty KM, Steckling N, Lettmeier B. Mercury exposure and children's health. Curr Probl Pediatr Adolesc Health Care 2010;40:186-215. DOI PubMed PMC

4. Camacho A, Mejía D. The health consequences of aerial spraying illicit crops: The case of Colombia. J Health Econ 2017;54:147-60. DOI PubMed

5. Dias M, Rocha R, Soares RR. Glyphosate use in agriculture and birth outcomes of surrounding populations. Documentos de Trabajo LACEA, 2019. Available from: http://econ.hunter.cuny.edu/wp-content/uploads/2019/04/Dias-Rocha-Soares-2019.02.06.pdf [Last accessed on 27 Apr 2021]. 